\title{
Factors controlling decomposition rates of fine root litter in temperate forests and grasslands
}

\author{
Emily F. Solly • Ingo Schöning • Steffen Boch • Ellen Kandeler • Sven Marhan • \\ Beate Michalzik • Jörg Müller • Jakob Zscheischler • Susan E. Trumbore • \\ Marion Schrumpf
}

Received: 19 November 2013 / Accepted: 12 May 2014 /Published online: 27 May 2014

(C) The Author(s) 2014. This article is published with open access at Springerlink.com

\begin{abstract}
Background and aims Fine root decomposition contributes significantly to element cycling in terrestrial ecosystems. However, studies on root decomposition rates and on the factors that potentially influence them are fewer than those on leaf litter decomposition. To study the effects of region and land use intensity on fine root decomposition, we established a large scale study in three German regions with different climate regimes and soil properties.
\end{abstract}

Responsible Editor: Kees Jan van Groenigen.

E. F. Solly $(\bowtie) \cdot$ I. Schöning $\cdot$ J. Zscheischler $•$

S. E. Trumbore $\cdot$ M. Schrumpf

Max-Planck Institute for Biogeochemistry,

Hans-Knöll-Str. 10, 07745 Jena, Germany

e-mail: esolly@bgc-jena.mpg.de

S. Boch

Institute of Plant Sciences and Botanical Garden, University

of Bern,

Altenbergrain 21, 3013 Bern, Switzerland

E. Kandeler $\cdot$ S. Marhan

Institute of Soil Science and Land Evaluation, University of Hohenheim,

Emil-Wolff-Str. 27, 70599 Stuttgart, Germany

B. Michalzik

Institute of Geography, University of Jena,

Löbdergraben 32, 07743 Jena, Germany

J. Müller

Institute of Biochemistry and Biology, University of Potsdam,

Maulbeerallee 1, 14469 Potsdam, Germany
Methods In 150 forest and 150 grassland sites we deployed litterbags (100 $\mu \mathrm{m}$ mesh size) with standardized litter consisting of fine roots from European beech in forests and from a lowland mesophilous hay meadow in grasslands. In the central study region, we compared decomposition rates of this standardized litter with root litter collected on-site to separate the effect of litter quality from environmental factors.

Results Standardized herbaceous roots in grassland soils decomposed on average significantly faster (24 \pm $6 \%$ mass loss after 12 months, mean \pm SD) than beech roots in forest soils $(12 \pm 4 \% ; p<0.001)$. Fine root decomposition varied among the three study regions. Land use intensity, in particular $\mathrm{N}$ addition, decreased fine root decomposition in grasslands. The initial lignin: $\mathrm{N}$ ratio explained $15 \%$ of the variance in grasslands and $11 \%$ in forests. Soil moisture, soil temperature, and C:N ratios of soils together explained $34 \%$ of the variance of the fine root mass loss in grasslands, and $24 \%$ in forests.

Conclusions Grasslands, which have higher fine root biomass and root turnover compared to forests, also have higher rates of root decomposition. Our results further show that at the regional scale fine root decomposition is influenced by environmental variables such as soil moisture, soil temperature and soil nutrient content. Additional variation is explained by root litter quality.

Keywords Fine roots - Decomposition · Land use intensity $\cdot$ Lignin:N ratio $\cdot$ Temperate ecosystems 


\section{Introduction}

Decomposition of plant litter is one of the main processes driving nutrient and carbon (C) cycling in terrestrial ecosystems and constitutes a major source of atmospheric $\mathrm{CO}_{2}$ (Hobbie 1992). While most of the previous studies on decomposition have focused on aboveground plant litter, recent isotopic analyses and assessments of root and shoot biomarkers indicate that root-derived $\mathrm{C}$ is retained more efficiently in soils and microorganisms than are $\mathrm{C}$ inputs from above ground plant litter (Kramer et al. 2010; Mendez-Millan et al. 2010). Due to the close proximity, root decomposition products are generally better incorporated into soil aggregates and more easily adsorbed to mineral surfaces than the ones of aboveground litter (Rasse et al. 2005; Sanaullah et al. 2011). Thus, plant litter, consisting of dead roots, is a major source of soil organic matter, the largest terrestrial pool of C (Schmidt et al. 2011).

Fine root decomposition rates do not mirror those of aboveground plant litter in temperate ecosystems (Bird and Torn 2006; Hobbie et al. 2010; Silver and Miya 2001), due to differences in the chemical composition of both litter types (Kögel-Knabner 2002), and because aboveground litter experiences different environmental conditions compared to belowground litter (Hobbie et al., 2010). Yet, only few experimental studies have been designed to identify predictors of fine root decomposition (Chen et al. 2002; Cusack et al. 2009; Fahey et al. 1988; Ostertag and Hobbie 1999), and even fewer extend beyond a single ecosystem (e.g. Long-term Intersite Decomposition Experiment (LIDET), Harmon et al. 2009). Previous studies have shown that root litter quality (mainly lignin, nitrogen $(\mathrm{N}), \mathrm{C}$ and calcium $(\mathrm{Ca})$ content) and climate factors such as temperature and precipitation are the primary controls of root decomposition. (Chen et al. 2002; Hobbie 2005; Silver and Miya 2001). However, little is known about how the direct and indirect effects of land use and management may influence fine root decomposition.

In grasslands, management practices such as fertilization, mowing and grazing can alter plant community structure, litter inputs and soil properties (Dickinson and Polwart 1982; Hobbie 2005; Semmartin et al. 2008). Some studies found that fertilization increases the decomposition of plant litter, due to higher $\mathrm{N}$ availability (Carreiro et al. 2000; Hobbie and Vitousek 2000). In contrast, other studies observed either no significant change or a suppression of decomposition rates as a response to higher fertilization regimes (Bryant et al. 1998). The contrasting responses to $\mathrm{N}$ additions across studies may be partly explained by differences in sitespecific atmospheric $\mathrm{N}$ deposition and by litter quality (Knorr et al. 2005). However, it is unclear how N fertilization alters root decomposition. Long-term grazing and mowing activities may affect root decomposition directly by altering the plant species composition and soil decomposer communities (Bardgett et al. 1998), or indirectly through changes in soil properties such as bulk density and soil moisture (e.g. through trampling) (Sankaran and Augustine 2004; Taboada and Lavado 1988).

In forests, thinning and harvesting can lead to soil degradation via soil compaction (Berthrong et al. 2009; Liao et al. 2010), which in turn might alter fine root decomposition rates due to changes in the aeration of the soil and the volumetric soil moisture content. Further, these practices as well as tree species selection may lead to variations in soil $\mathrm{C}$ and nutrient contents which may result in changes of the decomposer community. Higher temperature and moisture in more heavily thinned forests can further result in faster root decomposition although responses may vary among forests of different dominant tree species (Cortina and Vallejo 1994; Prescott et al. 2000). The goal of this study was to quantify root litter decomposition rates in differently managed temperate grasslands and forests, and to disentangle the effects of litter quality from environmental site effects.

In terrestrial ecosystems, decomposition of plant litter is commonly assessed using the litterbag method, which consists of enclosing plant tissue of known mass and chemical composition in a screened container (Bocock and Gilbert 1957) that is placed in or on top of the soil. When adopting the litterbag approach some artefacts need to be considered, such as microclimate alterations and exclusion of specific fauna size classes due to the selection of small mesh sizes. Nevertheless, the litterbag method is helpful to study decomposition especially if comparing decomposition rates occurring in different ecosystems and regions in a consistent way (Kurz-Besson et al. 2005). Meta-analyses have been used in previous studies to synthesize root decomposition (for example Silver and Miya 2001). The main caveat of the meta-analysis approach is that it compares decomposition rates derived from smaller scale root decomposition studies which adopted different methodologies (i.e. diverse litterbag mesh sizes, enclosure of root litter with diverse quality, and deployment at different soil depth). To study fine root decomposition at a 
large spatial scale in a comparative way, we used a standardized methodology for a range of ecosystems with different soil types, land uses and climate.

Our main objective was to quantify root litter decomposition after 12 months in differently managed temperate grasslands and forests. We were further interested in understanding whether environmental site conditions (including the microbial decomposer abundance) have a stronger impact on decomposition than differences in root litter quality between grasslands and forests. We deployed litterbags containing standardized herbaceous fine roots in 150 grassland plots and European beech roots in 150 forest plots in three German study regions managed with different land use intensities. Moreover, we compared the mass loss rates of standardized root litter with the rates for root litter collected on-site for one of the three regions (50 forest and 50 grassland plots). We hypothesized that root decomposition rates of standardized root litter would vary between the three study regions, reflecting differences in climate and soil properties. We also hypothesized that decomposition of onsite collected root litter would be affected by management practices, specifically fertilization, grazing and mowing activities in grasslands, and by different disturbance intensity and tree species selection in forests.

\section{Material and methods}

Study regions, management data, vegetation survey

Our study was carried out in the Biodiversity Exploratories (Fischer et al. 2010) which comprise a variety of forests and grasslands under different land use intensities in three regions within Germany. The Schwäbische Alb (ALB) is situated in south-western Germany, the Hainich-Dün (HAI) in central Germany, and the Schorfheide-Chorin (SCH) in north-eastern Germany. Each study region includes 50 forest plots and 50 grassland plots. In SCH 27 grassland plots have been established on organic soils (Histosols and Gleysols) and 23 on mineral soils. The three study regions differ in climate, altitude, and soil characteristics (Table 1).

In grasslands a land use intensity index (LUI) was calculated using landowner surveys. The LUI summarizes the individual land uses by summing up values for fertilization ( $\mathrm{kg} \mathrm{N}$ per hectare per year), mowing (number of cuts per hectare per year), and grazing intensities (livestock units per hectare per year) which have been normalized by the mean of the region (Blüthgen et al. 2012). To evaluate land use and disturbance intensity in the forests we used the LUDI index (Luyssaert et al. 2011). This index combines values of stand density and diameter at breast height for a relatively unmanaged forest and different management schemes, in conjunction with self-thinning values.

In 2009, we recorded vegetation data in $20 \mathrm{~m} \times 20 \mathrm{~m}$ forest plots in spring and summer (for details see Boch et al. 2013), and in $4 \mathrm{~m} \times 4 \mathrm{~m}$ grassland plots only once in summer (for details see Socher et al. 2013). We identified all vascular plant species and estimated their percentage cover. To assess the diversity of the vascular plant species in forest plots, we combined the spring and summer records to consider early and late emerging plants. For both, grassland and forest sites, we calculated the "Shannon Index" as a measure of plant species
Table 1 Main geographical and environmental characteristics of the three study regions:

Schwäbische Alb, Hainich-Dün, Schorfheide-Chorin

\begin{tabular}{|c|c|c|c|}
\hline & Schwäbische Alb & Hainich-Dün & Schorfheide-Chorin \\
\hline Location & SW Germany & Central Germany & NE Germany \\
\hline Coordinates & $\mathrm{N} 48^{\circ} 26^{\prime}$ E $9^{\circ} 23^{\prime}$ & $\mathrm{N} 51^{\circ} 9^{\prime} \mathrm{E} 10^{\circ} 28^{\prime}$ & $\mathrm{N} 53^{\circ} 0^{\prime} \mathrm{E} 13^{\circ} 46^{\prime}$ \\
\hline Area [km2] & $\sim 422$ & $\sim 1,300$ & $\sim 1,300$ \\
\hline Soil type forest & $\begin{array}{l}\text { Cambisol (eutric)- } \\
\text { Leptosol }\end{array}$ & Luvisol & Cambisol (dystric) \\
\hline Soil type grassland & Leptosol-Cambisol & $\begin{array}{l}\text { Cambisol-Stagnosol- } \\
\text { Vertisol }\end{array}$ & $\begin{array}{l}\text { Histosol-Gleysol-Cambisol- } \\
\text { Luvisol-Albeluvisol }\end{array}$ \\
\hline Altitude a.s.1 [m]. & $460-860$ & $285-550$ & $3-140$ \\
\hline $\begin{array}{l}\text { Mean annual } \\
\text { temperature } \\
\text { (MAT) }\left[{ }^{\circ} \mathrm{C}\right]\end{array}$ & $6.0-7.0$ & $6.5-8.0$ & $8.0-8.5$ \\
\hline $\begin{array}{l}\text { Mean annual } \\
\text { precipitation }[\mathrm{mm}]\end{array}$ & $700-1,000$ & $500-800$ & $500-600$ \\
\hline
\end{tabular}


diversity (Shannon 1948) (Eq. 1):

$H=-\sum_{i=1}^{n} p i \ln p i$

where $\mathrm{H}$ corresponds to entropy in this case equivalent to the Shannon Index, $p i$ is the percentage cover of individuals in the sampling area represented by species $i$ and is assessed by the quotient of number of individuals of species $i\left(N_{i}\right)$ and the total number of individuals $(N)$. Thus, the maximum diversity possible for $N$ individuals occurs when all species have the same percentage cover when each individual belongs to a different species. We further distinguished annual and perennial species and calculated their number per plot.

Soil temperature and moisture

Soil temperature and soil moisture were measured continuously in each plot every $10 \mathrm{~min}$ with ground surface temperature sensors (Meier NT Type 2021, Zwönitz, Germany) and soil humidity probes (DeltaT ML2X, Cambridge, $\mathrm{UK}$ ) at a soil depth of $10 \mathrm{~cm}$. In this study, we used the 6 and 12 months averages of soil temperature and volumetric soil moisture. We also calculated the number of days during which the soil was frozen $\left(-0^{\circ} \mathrm{C}\right)$ for each plot. Due to gap periods during the measurements, complete data on soil temperature was only available for 187 and soil moisture for 274 of the 300 plots.

Root collection, abiotic soil properties and microbial biomass

In each of the 300 plots we collected 14 mineral soil cores with a split tube sampler (diameter of $5 \mathrm{~cm}$ ) along two $20 \mathrm{~m}$ transects in grasslands and $40 \mathrm{~m}$ transects in forests in May 2011. Organic layers in forests and aboveground plant parts in grasslands were removed before coring. We then prepared a composite sample from the 14 mineral soil cores by mixing the upper $10 \mathrm{~cm}$ of the mineral soil. Roots were removed from the composite sample, cooled to $4{ }^{\circ} \mathrm{C}$ for soil analysis (root biomass, texture, $\mathrm{pH}$ and $\mathrm{C}$ and $\mathrm{N}$ concentrations, ) and frozen to $-20{ }^{\circ} \mathrm{C}$ for microbial biomass measurements, and transported to the laboratory. Soil samples were all sieved to $<2 \mathrm{~mm}$.

Microbial biomass $\mathrm{C}$ was estimated by chloroformfumigation-extraction (Vance et al. 1987). In brief, $10 \mathrm{~g}$ soil (fresh weight) of a homogeneous subsample of each plot was fumigated under vacuum with ethanol-free chloroform in a desiccator for $24 \mathrm{~h}$. After removing the chloroform, samples were extracted by adding $40 \mathrm{ml}$ of a $0.5 \mathrm{M} \mathrm{K}_{2} \mathrm{SO}_{4}$ solution (1:4 w/v soil/extractant ratio),

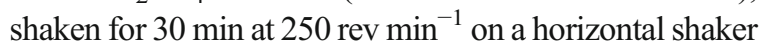
and centrifuged for $30 \mathrm{~min}$ at $4,422 \mathrm{~g}$. A second subsample of $10 \mathrm{~g}$ was treated similarly but without fumigation for the estimation of $0.5 \mathrm{M} \mathrm{K}_{2} \mathrm{SO}_{4}$ solution extractable organic C. Organic $\mathrm{C}$ in the supernatants was measured with a DOC/TN-analyser (Multi N/C 2100S, Analytik Jena, Jena, Germany). Extractable organic $\mathrm{C}$ content of the non-fumigated samples was subtracted from $\mathrm{C}$ content of the fumigated samples and resulted in extractable microbial biomass. For estimation of total microbial biomass a $\mathrm{k}_{\mathrm{ec}}$-factor of 0.45 was used (Joergensen 1996).

Soil samples were air dried. The dry biomass of the washed fine roots was weighed after oven-drying the root samples at $40{ }^{\circ} \mathrm{C}$. To evaluate the soil texture we determined the percentage of sand $(2-0.063 \mathrm{~mm})$, silt $(0.063-0.002 \mathrm{~mm})$ and clay $(<0.002 \mathrm{~mm})$ in the soil samples. We separated soil particles and size classes by sieving and sedimentation procedures (DIN-ISO 11277). We determined the $\mathrm{pH}$ values of our composite soil samples in duplicate using a $0.01 \mathrm{M} \mathrm{CaCl}_{2}$ solution. The soil solution ratio was 1:2.5.

Soil subsamples were ground in a ball mill (RETSCH MM200, Retsch, Haan, Germany). Total C and N concentrations were determined by dry combustion in an elemental analyser (VarioMax, Hanau, Germany). To evaluate the concentration of organic $\mathrm{C}$ in each soil sample we determined the amount of inorganic $\mathrm{C}$ by removing all organic carbon at a temperature of $450{ }^{\circ} \mathrm{C}$ for $16 \mathrm{~h}$, and subtracted this value from the total $\mathrm{C}$ concentration.

Chemical composition of fine roots

To identify the initial quality, subsamples of the root litter were ground in a ball mill (RETSCH MM200, Retsch, Haan, Germany). Total C and N concentrations were determined using an elemental analyzer (Vario EL, Elementar, Hanau, Germany). Concentrations of $\mathrm{Ca}$, magnesium $(\mathrm{Mg})$, aluminium $(\mathrm{Al})$ and phosphorus $(\mathrm{P})$ were measured using inductively coupled plasma-optical emission spectrometry (ICP-OES, Optima 3300 DV, Perkin Elmer, Norwalk, USA), after $50 \mathrm{mg}$ of root material were diluted in $3 \mathrm{ml}$ of $\mathrm{HNO}_{3} 65 \%$, (Merck, Darmstadt, Germany) and microwave digested at high pressure (Multiwave, Anton Paar, Graz, Austria) (Raessler et al. 2005). Lignin and holocellulose content (ideally composed by cellulose and hemicellulose) were 
estimated from thermogravimetric analysis in Argon atmosphere (TGA/SDTA851 ${ }^{\mathrm{e}}$ Mettler Toledo, GmbH, Giessen, Germany) (Yang et al. 2005). Temperature programming consisted of an initial isothermal phase at a temperature of $100{ }^{\circ} \mathrm{C}$ for $5 \mathrm{~min}$, a dynamic phase with a heating rate of $40{ }^{\circ} \mathrm{C} \mathrm{min}^{-1}$ from $100{ }^{\circ} \mathrm{C}$ to $1,000{ }^{\circ} \mathrm{C}$, and a second isothermal phase for $10 \mathrm{~min}$ at a temperature of $1,000{ }^{\circ} \mathrm{C}$. To prevent heat and mass transfer limitations, small samples (5 to $10 \mathrm{mg}$ ) were used. Weight loss and heating rate were continuously recorded. We calculated the amounts of lignin and holocellulose by dividing the biomass pyrolysis in the following ranges: $<220^{\circ} \mathrm{C}$, moisture evolution; 220 $400{ }^{\circ} \mathrm{C}$, holocellulose decomposition; $>400{ }^{\circ} \mathrm{C}$, lignin decomposition as indicated by Yang et al. (2005). As reference materials we used pure lignin (alkali, low sulfonate content) and cellulose powder.

\section{Root litter decomposition experiments}

We conducted two litterbag decomposition experiments using two different litter types: 1) we studied decomposition of standardized root litter at all 300 plots in forests and grasslands of the three regions, and 2) we used onsite collected material only in plots of the HAI region. As standard material for the forest sites we used fine roots collected from 2 year old European beech saplings (Fagus sylvatica L.) grown in sand. As standard material for the grassland sites, we used fine roots which we collected from a $16 \mathrm{~m}^{2}$ area in a lowland mesophilous hay meadow belonging to the alliance Arrhenatherion elatoris W. Koch (Isserstedt, Thuringia, Germany, 50 $57^{\prime} 30.3^{\prime \prime} \mathrm{N} 11^{\circ} 31^{\prime} 20.5^{\prime \prime} \mathrm{E}$ ).

We removed the mineral-soil particles attached to the roots, by carefully washing the roots with distilled water in a $63 \mu \mathrm{m}$ sieve. In addition, we suspended the root material in a tray containing distilled water to remove the more adherent mineral particles. We separated the fine roots $(<2 \mathrm{~mm}$ diameter) from the coarse roots and dried all samples at $40{ }^{\circ} \mathrm{C}$ to constant weight in a forceair oven. We put $0.5 \mathrm{~g}$ of dry fine root litter (mass selected according to average local root biomass distributions in top-soils) into a $10 \mathrm{~cm} \times 10 \mathrm{~cm}$ litterbag made of a $100 \mu \mathrm{m}$ polyester mesh screening to allow microfaunal decomposition (Schwegmann FiltrationsTechnik GmbH, Grafschaft-Gelsdorf, Germany). The variation of the initial weight was $(0.508 \pm 0.006 \mathrm{~g})$. We individually labelled each litterbag with a stainless steel label which was placed inside the enclosure and measured the total mass of each litterbag.

For each of the two experimental set-ups we tied together three litterbags, representing replicates containing the same material type (standard litter and on-site collected litter) for every collection time. In October 2011, we placed them approximately $3 \mathrm{~m}$ apart from meteorological stations. The litterbags were distributed vertically into a $10 \mathrm{~cm}$ deep slit in the mineral soil. After 6 months (in April 2012) and after 12 months (October 2012) respectively we collected three litterbags at each site containing standardized material. In addition, we sampled three litterbags containing on-site collected material in all of the $100 \mathrm{HAI}$ plots in October 2012. The collected litterbags were transported to the laboratory where we gently removed the ingrown material and cleaned the fine root-litter from adherent soil particles. After drying at $40{ }^{\circ} \mathrm{C}$ we calculated the fine root decomposition rates (mass loss in \%) for each plot as the mean mass loss of the three litterbags collected at each collection date (standard deviations for the three replicates ranged between 0.1 and $3.5 \%$ after 6 months of decomposition and between 0.1 and $8.2 \%$ after 12 months of decomposition). We further used the negative exponential single-pool decomposition model (Olson 1963) to estimate the root litter decomposition rates $(k)$, though we recognize that this represents only initial decomposition rates (12 months) and that these slow over time in most decomposition experiments (e.g. Sun et al. 2012).

\section{Statistics}

We conducted statistical analyses with $\mathrm{R}$, version 3.0.2 (R Development Core Team 2013). Throughout the manuscript we present data as means \pm standard error. Two way analysis of variance (ANOVA) accompanied by Holm's test was used to examine statistical differences between the mass loss of standardized fine root litter (after 6 and 12 months), soil moisture, soil temperature, soil properties, land use and root biomass, in grassland and forest plots among the regions (in the $\mathrm{SCH}$ study region we additionally distinguished between organic soils (Histosols and Gleysols) and mineral soils). Significant differences between fine root litter chemistry 
of grasslands and forests, and between standardized and on-site collected root material were tested with Student's $t$-test.

To detect the environmental predictors of fine root decomposition in grasslands and forests, we applied general linear models (GLM). In grasslands we conducted three separate GLMs, one grouping all three study regions, one for the mineral soils in the three study regions and one for $\mathrm{SCH}$ to evaluate the difference between organic and mineral soils. To check whether complex interactions between explanatory variables were present and to select which variables should be included in the GLM and in which order, before conducting each GLM we fitted a tree model (Crawley 2007). In the tree model analysis we included the following variables: soil properties $(\mathrm{pH}$, organic $\mathrm{C}$ content, $\mathrm{C}: \mathrm{N}$ ratio and texture, microbial biomass), climate (soil temperature and moisture), land use (LUI and LUDI), plant diversity (Shannon index) and number of perennial species. We calculated the variance inflation factor (VIF) between the variables selected from the fitting of the tree models to prevent multicollinearity. We manually simplified all GLMs to the minimum adequate model by using stepwise selection of variables until all terms contained in the model were significant (Crawley 2007). We then checked the model assumptions using the diagnostic plot function in $\mathrm{R}$ (Crawley 2007).

To assess whether environmental variables have a stronger impact on decomposition than root litter chemistry differences within grassland and forest sites, we used multiple regression analysis. As for the GLMs, we fitted a tree model (one for grasslands and one for forests) before conducting multiple regressions. Root litter chemistry (content of $\mathrm{C}, \mathrm{N}, \mathrm{Ca}$, $\mathrm{Mg}, \mathrm{Al}, \mathrm{P}$, holocellulose, $\mathrm{C}: \mathrm{N}$ and lignin: $\mathrm{N}$ ratio) was included in the tree models in addition to the environmental variables. Quadratic terms of each variable were included in the model to check for non-linear responses.

We used partial linear regression to determine the amounts of variations explained by land use and the other environmental variables on decomposition of standardized fine root litter in grasslands (Legendre 2008). We used this method also to distinguish between the variation explained by environmental and root-litter chemistry variables on fine root decomposition in grasslands and forests of the HAI region. The variables we adopted in the partial linear regression were the ones which were selected from the minimum adequate GLM and the multiple regressions.

\section{Results}

Soil characteristics and root biomass

The soils of the ALB study region showed higher volumetric soil moisture content than the ones in $\mathrm{HAI}$ and $\mathrm{SCH}$ for both grasslands and forests during 6 and 12 months of decomposition. Soil temperatures were higher in $\mathrm{SCH}$ than in the ALB and HAI regions (Table 2). The soils in the HAI study region were on average frozen for more days during the 12 months period (7 days) than ALB (5 days) and $\mathrm{SCH}$ (4 days).

In grassland soils, we found on average higher clay contents, $\mathrm{pH}$ values, $\mathrm{C}: \mathrm{N}$ ratios and microbial biomass than in forest soils (Table 3). Soil properties also differed between study regions (Table 3 ). Organic $\mathrm{C}$ and microbial $\mathrm{C}$ were positively related to clay contents $(r=0.68, r=0.70)$ in mineral soils. Microbial biomass was also positively correlated with the soil organic $\mathrm{C}$ content $(r=0.65)$. The organic soils of the $\mathrm{SCH}$ contained higher soil organic $\mathrm{C}$ and microbial biomass compared to the mineral soils of the study region. In grasslands, fine root biomass was highest in the mineral soils of the $\mathrm{SCH}$ followed by HAI, the organic soils in $\mathrm{SCH}$, and then ALB, whereas in the forests root biomass was greater in the HAI study region than in $\mathrm{SCH}$ and ALB.

Fine root initial chemical composition

C concentrations, estimated lignin content and lignin: $\mathrm{N}$ ratios were lower, and $\mathrm{P}$ and holocellulose content were higher in root samples collected in grasslands than those collected in the forest sites (Table 4). Variability in the chemical quality of roots was greater for root material collected across 50 plots (both for forest and grassland) compared to standard material derived from a single site (grassland) or species (forest). The standardized grassland root litter differed significantly from fine root litter collected in the HAI grassland plots, with 
Table 2 Soil moisture and temperature over 6 and 12 months, in all study regions (mean $\pm \mathrm{SD}$ ). Soil temperature is expressed in ${ }^{\circ} \mathrm{C}$ and soil moisture is expressed in percentage of volumetric water content $(\% \mathrm{VWC})$. Significant differences between study regions are indicated by lowercase letters, and between land use types by capital letters according to Holm's test $(p<0.05)(n=274$ for soil moisture, $n=187$ for soil temperature)

\begin{tabular}{|c|c|c|c|c|c|}
\hline \multirow[t]{2}{*}{ Land use } & \multirow[t]{2}{*}{ Study region } & \multicolumn{2}{|c|}{ Soil moisture } & \multicolumn{2}{|c|}{ Soil temperature } \\
\hline & & 6 months & 12 months & 6 months & 12 months \\
\hline & & $\%$ & $\%$ & ${ }^{\circ} \mathrm{C}$ & ${ }^{\circ} \mathrm{C}$ \\
\hline \multirow[t]{4}{*}{ Forest } & All plots & $26 \pm 10^{\mathrm{A}}$ & $26 \pm 10^{\mathrm{A}}$ & $7 \pm 5^{\mathrm{A}}$ & $9 \pm 4^{\mathrm{A}}$ \\
\hline & Schwäbische Alb & $34 \pm 7^{\mathrm{a}}$ & $34 \pm 7^{\mathrm{a}}$ & $5 \pm 3^{\mathrm{a}}$ & $7 \pm 2^{\mathrm{a}}$ \\
\hline & Hainich-Dün & $29 \pm 6^{\mathrm{b}}$ & $29 \pm 6^{\mathrm{b}}$ & $5 \pm 1^{\mathrm{a}}$ & $9 \pm 2^{\mathrm{ab}}$ \\
\hline & Schorfheide-Chorin & $15 \pm 3^{\mathrm{c}}$ & $15 \pm 4^{\mathrm{c}}$ & $10 \pm 5^{\mathrm{b}}$ & $10 \pm 4^{\mathrm{b}}$ \\
\hline \multirow[t]{4}{*}{ Grassland } & All plots & $37 \pm 9^{\mathrm{B}}$ & $34 \pm 9^{\mathrm{B}}$ & $7 \pm 4^{\mathrm{A}}$ & $11 \pm 4^{\mathrm{B}}$ \\
\hline & Schwäbische Alb & $41 \pm 4^{\mathrm{d}}$ & $40 \pm 4^{\mathrm{d}}$ & $5 \pm 2^{\mathrm{a}}$ & $8 \pm 2^{\mathrm{a}}$ \\
\hline & Hainich-Dün & $33 \pm 6^{\mathrm{a}}$ & $29 \pm 4^{\mathrm{b}}$ & $6 \pm 2^{\mathrm{a}}$ & $11 \pm 3^{b}$ \\
\hline & Schorfheide-Chorin & $34 \pm 11^{\mathrm{a}}$ & $29 \pm 10^{\mathrm{b}}$ & $12 \pm 6^{\mathrm{c}}$ & $14 \pm 4^{\mathrm{c}}$ \\
\hline
\end{tabular}

lower $\mathrm{N}(p<0.05)$ and holocellulose content $(p<0.001)$. The higher $\mathrm{N}$ content and variability for the roots collected on-site compared to the standardized material in grasslands probably results from the wide range of fertilization regimes. The $\mathrm{Ca}$ and $\mathrm{Al}$ concentrations were lower in the standardized compared to on-site collected root material (Table 4). The standardized root material used in forests differed from the average of the fine root litter collected on the HAI forest sites, with higher $\mathrm{C}(p<0.001)$ and lignin $(p<0.05)$ content, possibly due to variable contributions of understory roots in on-site collected samples. In addition, standardized beech roots had lower $\mathrm{Mg}, \mathrm{Ca}$ and $\mathrm{Al}$ content than the root material collected on site in the HAI forest plots $(p<0.05)$.

Fine root mass loss in the standard litter across three regions

Herbaceous standardized fine root litter deployed in grasslands lost more mass $(p<0.01)$ after 12 months ( $24 \pm 6 \%$ mass loss) compared to the mass loss of tree standardized fine root litter in forests $(12 \pm$

Table 3 Soil properties and dry root biomass among different land uses and study regions (mean \pm SD). Significant differences between study regions are indicated by lowercase letters and between forests and grasslands by capital letters according to Holm's test $(p<0.05)$

\begin{tabular}{|c|c|c|c|c|c|c|c|c|c|c|}
\hline Land use & Study region & $\mathrm{n}$ & $\begin{array}{l}\text { Sand } \\
\mathrm{g} \mathrm{kg}^{-1}\end{array}$ & $\begin{array}{l}\text { Clay } \\
\mathrm{g} \mathrm{kg}^{-1}\end{array}$ & $\mathrm{pH}$ & $\begin{array}{l}\text { Total N g } \\
\mathrm{kg}^{-1}\end{array}$ & $\begin{array}{l}\text { Organic } \\
\mathrm{C} \mathrm{g} \mathrm{kg}^{-1}\end{array}$ & $\mathrm{C}: \mathrm{N}$ & $\begin{array}{l}\text { Microbial } \\
\text { biomass } \\
\mu \mathrm{g} \mathrm{g}^{-1}\end{array}$ & $\begin{array}{l}\text { Root } \\
\text { biomass } \\
\mathrm{g} \mathrm{m}^{-2}\end{array}$ \\
\hline \multirow[t]{4}{*}{ Forest } & All plots & 150 & $329 \pm 387^{\mathrm{A}}$ & $281 \pm 203^{\mathrm{A}}$ & $4 \pm 1^{\mathrm{A}}$ & $3 \pm 2^{\mathrm{A}}$ & $40 \pm 20^{\mathrm{A}}$ & $15 \pm 3^{\mathrm{A}}$ & $436 \pm 308^{A}$ & $98 \pm 90^{\mathrm{A}}$ \\
\hline & Schwäbische Alb & 50 & $60 \pm 46^{\mathrm{a}}$ & $496 \pm 105^{\mathrm{a}}$ & $5 \pm 1^{\mathrm{a}}$ & $5 \pm 1^{\mathrm{a}}$ & $53 \pm 14^{\mathrm{a}}$ & $13 \pm 1^{\mathrm{a}}$ & $737 \pm 220^{\mathrm{a}}$ & $67 \pm 56^{\mathrm{a}}$ \\
\hline & Hainich-Dün & 50 & $58 \pm 18^{\mathrm{a}}$ & $301 \pm 99^{\mathrm{b}}$ & $5 \pm 1^{\mathrm{b}}$ & $3 \pm 1^{\mathrm{b}}$ & $36 \pm 10^{\mathrm{ab}}$ & $13 \pm 1^{\mathrm{a}}$ & $449 \pm 214^{\mathrm{b}}$ & $155 \pm 120^{\mathrm{b}}$ \\
\hline & Schorfheide-Chorin & 50 & $871 \pm 61^{\mathrm{b}}$ & $45 \pm 19^{c}$ & $3 \pm 0.1^{\mathrm{c}}$ & $1 \pm 0.2^{b}$ & $21 \pm 5^{\mathrm{b}}$ & $19 \pm 3^{\mathrm{b}}$ & $123 \pm 38^{\mathrm{c}}$ & $73 \pm 45^{\mathrm{a}}$ \\
\hline \multirow[t]{5}{*}{ Grassland } & All plots & 150 & $190 \pm 228^{B}$ & $378 \pm 192^{\mathrm{B}}$ & $7 \pm 1^{\mathrm{B}}$ & $7 \pm 5^{\mathrm{B}}$ & $72 \pm 64^{B}$ & $10 \pm 1^{\mathrm{B}}$ & $656 \pm 291^{\mathrm{B}}$ & $175 \pm 149^{\mathrm{B}}$ \\
\hline & Schwäbische Alb & 50 & $57 \pm 45^{\mathrm{a}}$ & $536 \pm 134^{\mathrm{d}}$ & $6 \pm 1^{\mathrm{d}}$ & $6 \pm 1^{\mathrm{a}}$ & $65 \pm 14^{\mathrm{a}}$ & $10 \pm 1^{\mathrm{c}}$ & $748 \pm 210^{\mathrm{a}}$ & $35 \pm 30^{\mathrm{d}}$ \\
\hline & Hainich-Dün & 50 & $58 \pm 23^{\mathrm{a}}$ & $423 \pm 130^{\mathrm{e}}$ & $7 \pm 1^{\mathrm{e}}$ & $4 \pm 1^{\mathrm{ab}}$ & $46 \pm 12^{\mathrm{a}}$ & $10 \pm 1^{\mathrm{c}}$ & $594 \pm 169^{d}$ & $215 \pm 87^{\mathrm{e}}$ \\
\hline & $\begin{array}{l}\text { Schorfheide-Chorin } \\
\text { mineral soils }\end{array}$ & 23 & $643 \pm 101^{\mathrm{c}}$ & $137 \pm 93^{\mathrm{f}}$ & $6 \pm 1^{d}$ & $2 \pm 1^{b}$ & $21 \pm 4^{\mathrm{b}}$ & $10 \pm^{1 \mathrm{c}}$ & $236 \pm 62^{\mathrm{e}}$ & $246 \pm 122^{\mathrm{f}}$ \\
\hline & organic soils & 27 & $324 \pm 179^{d}$ & $216 \pm 119^{g}$ & $7 \pm 1^{\mathrm{e}}$ & $15 \pm 2^{\mathrm{d}}$ & $170 \pm 102^{\mathrm{c}}$ & $11 \pm 2^{\mathrm{c}}$ & $906 \pm 338^{\mathrm{f}}$ & $180 \pm 127^{\mathrm{e}}$ \\
\hline
\end{tabular}


Table 4 Chemical quality of the standardized fine root litter and the fine root litter collected on site in the Hainich-Dün and used in this study (mean $\pm \mathrm{SD}$ ). For the standardized material 20 replicates of fine root material were analysed. Significant differences between fine roots collected on-site and standardized material for grasslands and forests are indicated by lowercase letters according to Holm's test $(p<0.05)$

\begin{tabular}{lllllllllllll}
\hline Fine root material & Land use & $\mathrm{n}$. & $\mathrm{C}$ & $\mathrm{N}$ & $\mathrm{P}$ & $\mathrm{Ca}$ & $\mathrm{Mg}$ & $\mathrm{Al}$ & Holocellulose & Lignin & $\mathrm{C}: \mathrm{N}$ & Lignin:N \\
\hline \multirow{3}{*}{ Standardized } & & & $\mathrm{mg} / \mathrm{g}$ & $\mathrm{mg} / \mathrm{g}$ & $\mathrm{mg} / \mathrm{g}$ & $\mathrm{mg} / \mathrm{g}$ & $\mathrm{mg} / \mathrm{g}$ & $\mathrm{mg} / \mathrm{g}$ & $\mathrm{mg} / \mathrm{g}$ & $\mathrm{mg} / \mathrm{g}$ & $\mathrm{mg} / \mathrm{g}$ & $\mathrm{mg} / \mathrm{g}$ \\
& Forests & 20 & $470 \pm 13^{\mathrm{a}}$ & $11 \pm 2^{\mathrm{a}}$ & $1^{\mathrm{a}}$ & $5^{\mathrm{a}}$ & $1^{\mathrm{a}}$ & $6 \pm 0^{\mathrm{a}}$ & $418 \pm 6^{\mathrm{a}}$ & $433 \pm 7^{\mathrm{a}}$ & $49 \pm 6^{\mathrm{a}}$ & $40 \pm 1^{\mathrm{a}}$ \\
& Grasslands & 20 & $433 \pm 17^{\mathrm{b}}$ & $8 \pm 1^{\mathrm{b}}$ & $2^{\mathrm{b}}$ & $6 \pm 1^{\mathrm{a}}$ & $3^{\mathrm{b}}$ & $5^{\mathrm{a}}$ & $585 \pm 7^{\mathrm{b}}$ & $251 \pm 5^{\mathrm{b}}$ & $53 \pm 3^{\mathrm{b}}$ & $31 \pm 1^{\mathrm{b}}$ \\
Collected on-site & Forest & 50 & $448 \pm 32^{\mathrm{c}}$ & $11 \pm 2^{\mathrm{a}}$ & $1^{\mathrm{a}}$ & $10 \pm 5^{\mathrm{b}}$ & $2 \pm 2^{\mathrm{b}}$ & $7 \pm 3^{\mathrm{b}}$ & $424 \pm 40^{\mathrm{a}}$ & $361 \pm 35^{\mathrm{c}}$ & $41 \pm 7^{\mathrm{c}}$ & $34 \pm 6^{\mathrm{c}}$ \\
& Grasslands & 50 & $400 \pm 24^{\mathrm{d}}$ & $11 \pm 3^{\mathrm{a}}$ & $2 \pm 1^{\mathrm{b}}$ & $9 \pm 4^{\mathrm{b}}$ & $2 \pm 3^{\mathrm{b}}$ & $8 \pm 3^{\mathrm{b}}$ & $510 \pm 32^{\mathrm{b}}$ & $259 \pm 13^{\mathrm{b}}$ & $38 \pm 9^{\mathrm{d}}$ & $24 \pm 5^{\mathrm{b}}$ \\
\hline
\end{tabular}

$4 \%$ ). The mass loss of fine root litter in both land uses nearly doubled from the first collection (6 months, over winter) to the second (a full year, including summer; Table 5). The mass loss of fine root litter was significantly faster in the SCH study region followed by ALB and HAI for both collection times (Table 5). Mass loss of standardized fine root material after 6 and 12 months of decomposition was correlated in grasslands $(r=0.51)$ and forests $(r=0.64)$ (Fig. 1). These not so high correlations may be related to the comparison of different root litterbags collected at different times in the same plots. We based our subsequent analyses on the mass loss of fine roots after 12 months decomposition.

Table 5 Mass loss of standard fine root litter and of the fine root litter collected on-site after 6 and 12 months of decomposition (mean $\pm \mathrm{SD}$ ). Significant differences between study regions are

\begin{tabular}{|c|c|c|c|c|c|c|}
\hline Fine root litter & Land use & Study region & $\mathrm{n}$ & $\begin{array}{l}\text { Mass loss after } \\
6 \text { months }(\%)\end{array}$ & $\begin{array}{l}\text { Mass loss after } \\
12 \text { months (\%) }\end{array}$ & k-values $\left(\right.$ year $^{-1}$ ) \\
\hline \multirow[t]{9}{*}{ Standardized } & \multirow[t]{4}{*}{ Forest } & All plots & 150 & $6 \pm 3^{\mathrm{A}}$ & $12 \pm 4^{\mathrm{A}}$ & $0.12 \pm 0.5^{\mathrm{A}}$ \\
\hline & & Schwäbische Alb & 50 & $6 \pm 2^{\mathrm{a}}$ & $11 \pm 3^{\mathrm{a}}$ & $0.12 \pm 0.03^{\mathrm{a}}$ \\
\hline & & Hainich-Dün & 50 & $4 \pm 2^{b}$ & $8 \pm 5^{\mathrm{b}}$ & $0.09 \pm 0.05^{\mathrm{b}}$ \\
\hline & & Schorfheide-Chorin & 50 & $8 \pm 2^{\mathrm{c}}$ & $16 \pm 2^{c}$ & $0.17 \pm 0.02^{\mathrm{c}}$ \\
\hline & \multirow[t]{5}{*}{ Grassland } & All plots & 150 & $12 \pm 5^{\mathrm{B}}$ & $24 \pm 6^{\mathrm{B}}$ & $0.27 \pm 0.8^{\mathrm{B}}$ \\
\hline & & Schwäbische Alb & 50 & $12 \pm 4^{\mathrm{d}}$ & $23 \pm 7^{\mathrm{d}}$ & $0.27 \pm 0.07^{\mathrm{d}}$ \\
\hline & & Hainich-Dün & 50 & $9 \pm 4^{\mathrm{c}}$ & $20 \pm 5^{\mathrm{e}}$ & $0.22 \pm 0.06^{\mathrm{e}}$ \\
\hline & & Schorfheide-Chorin mineral soils & 23 & $15 \pm 3^{\mathrm{e}}$ & $26 \pm 3^{\mathrm{f}}$ & $0.32 \pm 0.04^{\mathrm{f}}$ \\
\hline & & organic soils & 27 & $17 \pm 4^{\mathrm{e}}$ & $31 \pm 3^{\mathrm{g}}$ & $0.37 \pm 0.04^{\mathrm{g}}$ \\
\hline \multirow[t]{2}{*}{ Collected on site } & Forest & Hainich-Dün & 50 & - & $8 \pm 4^{\mathrm{Cb}}$ & $0.09 \pm 0.05^{\mathrm{Cb}}$ \\
\hline & Grassland & Hainich-Dün & 50 & - & $19 \pm 7^{\mathrm{De}}$ & $0.21 \pm 0.06^{\mathrm{De}}$ \\
\hline
\end{tabular}

Predictors of fine root mass loss (standardized litter)

Differences between study regions influenced fine root decomposition in grasslands and forests (Table 6b, 6d). Within all grasslands, the mass loss of the standardized fine root material was further influenced by the total organic $\mathrm{C}$ content present in the soil, the soil moisture and the LUI (adjusted $r^{2}=0.39$ ) (Table 6a). Partial linear regression analysis showed that the LUI explained $4 \%$ of the variation while organic $\mathrm{C}$, study region, and soil moisture together explained $24 \%$ of the variation. The effect of organic $\mathrm{C}$ and soil moisture was not observed in the model including only the mineral soils of the three study regions (Table 6b). In fact,

indicated by lowercase letters, and between forests and grasslands by capital letters according to Holm's test $(p<0.05)$ 

root litter after 6 and 12 months of decomposition across all study regions, for both grasslands and forests
Fig. 1 Comparison between the mass loss of standardized fine

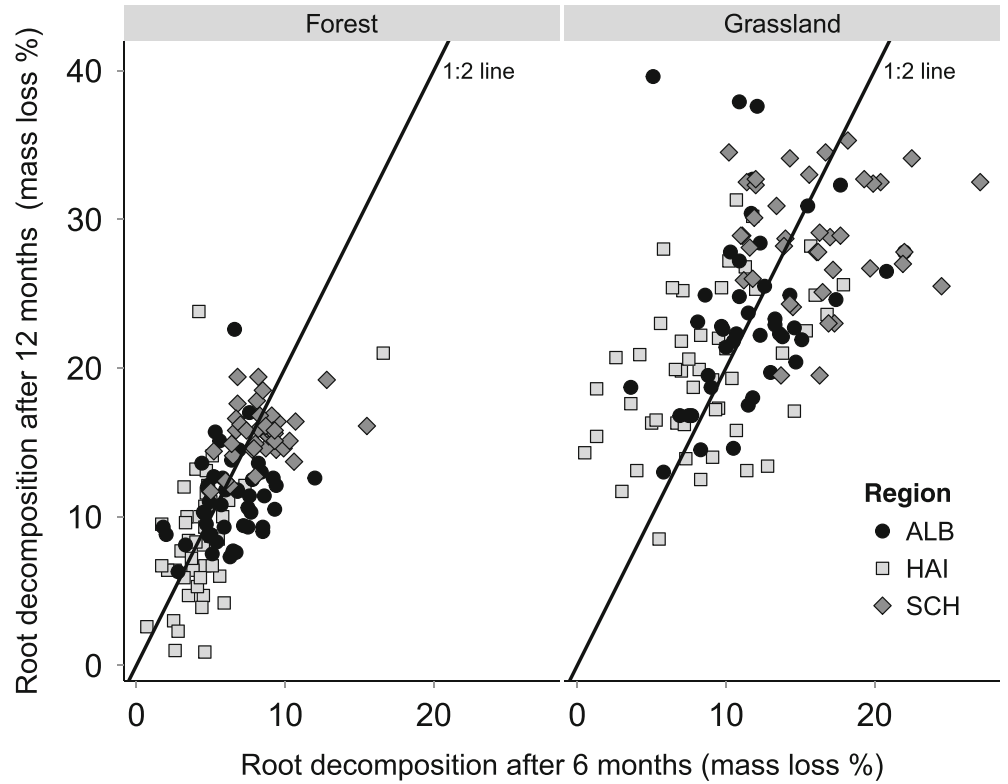

when excluding the organic soils present in the $\mathrm{SCH}$, fine root mass loss was explained by differences in study regions and LUI. The separation between organic and mineral soils in the $\mathrm{SCH}$ explained most of the variance of fine root mass loss in this study region followed by the LUI index (Table 6c). We checked the effect of fertilization, grazing and mowing intensities on fine root mass loss within the grasslands of all three study regions. The standardized fine roots decomposed faster in unfertilized plots than fertilized plots both after six months (unfertilized grasslands: $12 \pm 4 \%$; fertilized grasslands: $10 \pm 4 \%$, $p<0.01$ ) and after 12 months (unfertilized grasslands: $25 \pm 6 \%$; fertilized grasslands: $22 \pm 6 \%$, $p<0.01)$. Fine root mass loss did not differ significantly between grazed and not grazed plots and mowed and not mowed plots. In forests we did not observe an effect of land use on fine root decomposition.

Fine root mass loss for on-site collected litter in the HAI region

Despite differences in the initial fine root litter quality, the average mass loss of fine roots during the first 12 months of decomposition was similar between on-site collected root litter and the standardized root material in the HAI study region both for grasslands ( $20 \%$ mass loss) and forests ( $\sim 8 \%$ mass loss) (Table 5). Overall, the correlation between mass lost by on-site collected root litter versus standardized root litter was poor ( $r=0.44$ in grasslands and $r=0.10$ in forests) (Fig. 2).

Predictors of fine root mass loss (on-site collected litter)

According to our analysis fine root decomposition in grasslands was primarily positively related to the lignin: $\mathrm{N}$ ratio of roots and to soil $\mathrm{C}: \mathrm{N}$ ratios (Table 7a). We further observed a relation between fine root decomposition and soil moisture and soil temperature. The best linear model for predicting fine root mass loss in grasslands was highly significant $(p<0.001)$ with an adjusted $r^{2}$ value of 0.55 . We observed that in the grasslands the lignin: $\mathrm{N}$ ratio of fine roots was negatively correlated to the LUI index $(r=-0.64)$ (Fig. 3). In grasslands the lignin:N ratio explained $15 \%$ of the variation of fine root decomposition; while the sum of the environmental variables explained $34 \%$ of the variation (Fig. 4a).

In forests, fine root decomposition was negatively related to the lignin: $\mathrm{N}$ ratio of roots, followed by soil moisture and temperature (Table $7 \mathrm{~b}$ ). The best linear 
Table 6 Result of the best predictive model on decomposition rates (mass loss \%) of standardized fine root litter a) in all grasslands (mineral and organic soils, 150 plots) b) in the mineral soil of the grasslands c) in the grasslands of the Schorfheide-Chorin (mineral and organic soils, 50 plots) d) forests (150 plots), according to ANCOVA analysis. $* * * p<0.001, * * p<0.01,{ }^{*} p<0.05$

\begin{tabular}{llll}
\hline Coefficients & Df & Mean Sq & F value \\
\hline
\end{tabular}

a) Mass loss (standardized material, grasslands)

$\begin{array}{llll}\text { Organic C } & 1 & 119.6 & 4.9^{*} \\ \text { Study region } & 2 & 742.7 & 30.4^{* * *} \\ \text { Soil Moisture } & 1 & 140.3 & 5.7^{*} \\ \text { LUI } & 1 & 191.1 & 7.8^{* *} \\ & 109 & 24.5 & \end{array}$

Residuals $\quad 109 \quad 24.5$

b) Mineral soils Schwäbische Alb, Hainich-Dün, SchorfheideChorin. Mass loss (standardized material, grasslands)

$\begin{array}{llll}\text { Study region } & 2 & 330.42 & 12.30^{* *} \\ \text { LUI } & 1 & 176.9 & 0.01^{*} \\ \text { Residuals } & 92 & 30.2 & \end{array}$

c) Schorfheide-Chorin. Mass loss (standardized material, grasslands)

$\begin{array}{llll}\text { Mineral vs Organic soil } & 1 & 236.7 & 26.27^{* * *} \\ \text { LUI } & 1 & 50.2 & 5.57^{* *} \\ \text { Residuals } & 38 & 9.1 & \end{array}$

d) Mass loss (standardized material, forests)

\begin{tabular}{llll} 
Study region & 2 & 563.5 & $53.35^{* * * *}$ \\
Residuals & 132 & 10.6 & \\
\hline
\end{tabular}

model for predicting fine root decomposition in grasslands was highly significant $(p<0.001)$ with an adjusted
Table 7 Result of the best predictive model on decomposition rates (mass loss \%) of fine roots collected on-site in the a) HainichDün grasslands and b) Hainich-Dün forests, according to multiple regression analysis. ${ }^{* * *} p<0.001,{ }^{*} p<0.01,{ }^{*} p<0.05$

\begin{tabular}{lll}
\hline Coefficients & Estimate & Std. t value \\
& Error \\
& \\
& \\
\hline
\end{tabular}

a) Mass loss (on-site collected material, grasslands)

$\begin{array}{llll}\text { Intercept } & -233.80 & 95.83 & -2.44^{*} \\ \text { Lignin/N ratio } & 49.40 & 15.90 & 3.11^{* *} \\ \text { C/N ratio soil } & 25.26 & 9.83 & 2.57^{*} \\ \text { Soil Moisture } & 8.60 & 3.08 & 2.79^{* *} \\ \text { Soil Temperature) }^{2} & 0.18 & 0.7 & 2.58^{*} \\ \text { C:N ratio soil : Soil Moisture } & -0.97 & 0.32 & -3.05^{* *} \\ \text { Soil moisture : Soil } & 0.14 & 0.05 & 2.68^{*} \\ \quad \text { temperature } & & & \end{array}$

b) Mass loss (on-site collected material, forests)

\begin{tabular}{|c|c|c|c|}
\hline Intercept & 84.88 & 17.87 & $4.75 * * *$ \\
\hline Lignin/N ratio & -0.18 & 0.06 & $-2.89 * *$ \\
\hline Soil Moisture & -1.44 & 0.37 & $-3.94 * * *$ \\
\hline Soil Temperature & -10.04 & 2.82 & $-3.57 * *$ \\
\hline (Soil Temperature) $^{2}$ & 0.27 & 0.09 & $2.72 *$ \\
\hline $\begin{array}{l}\text { Soil moisture : Soil } \\
\text { temperature }\end{array}$ & 0.16 & 0.04 & $3.9 * * *$ \\
\hline
\end{tabular}

Residual standard error: 3.262 on $25^{\circ}$ of freedom, Residual standard error: 2.431 on $35^{\circ}$ of freedom

$r^{2}$ value of 0.42 . We further observed a decline in the lignin: $\mathrm{N}$ ratio with the number of tree species present on
Fig. 2 Relationship between the mass loss of fine roots collected on-site and fine roots used as standardized material in the Hainich-Dün study region after 12 months of decomposition

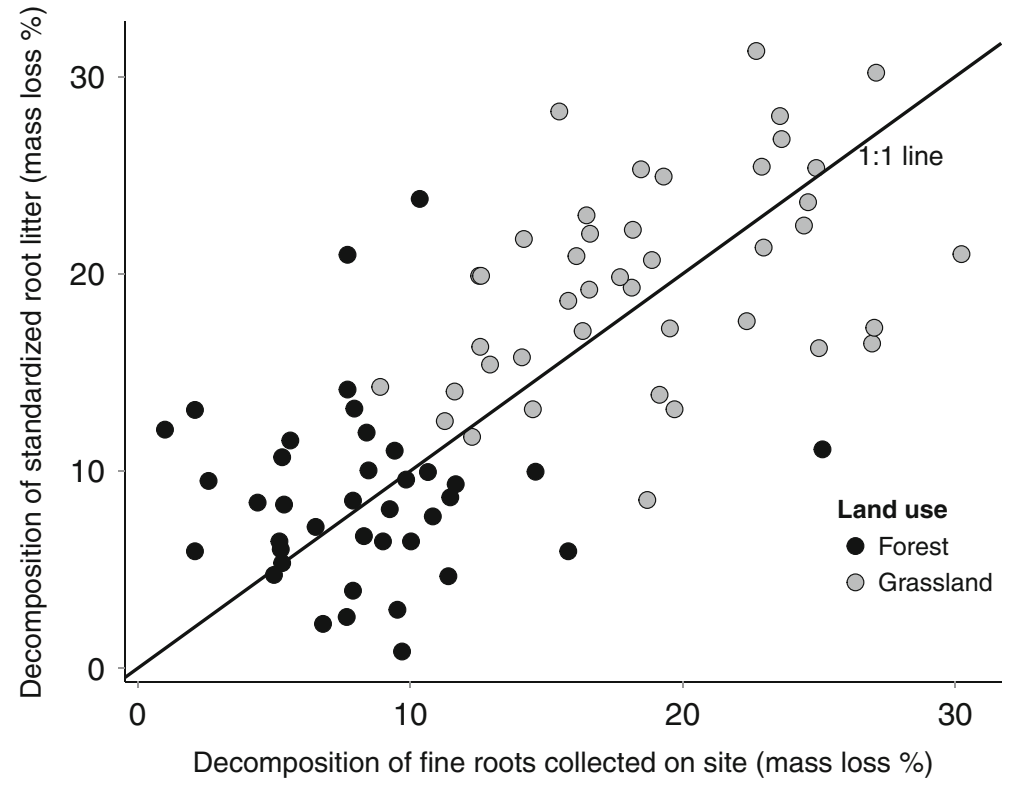


Fig. 3 Regression between the lignin: $N$ ratio and the land use intensity index (LUI) in the Hainich-Dün study region

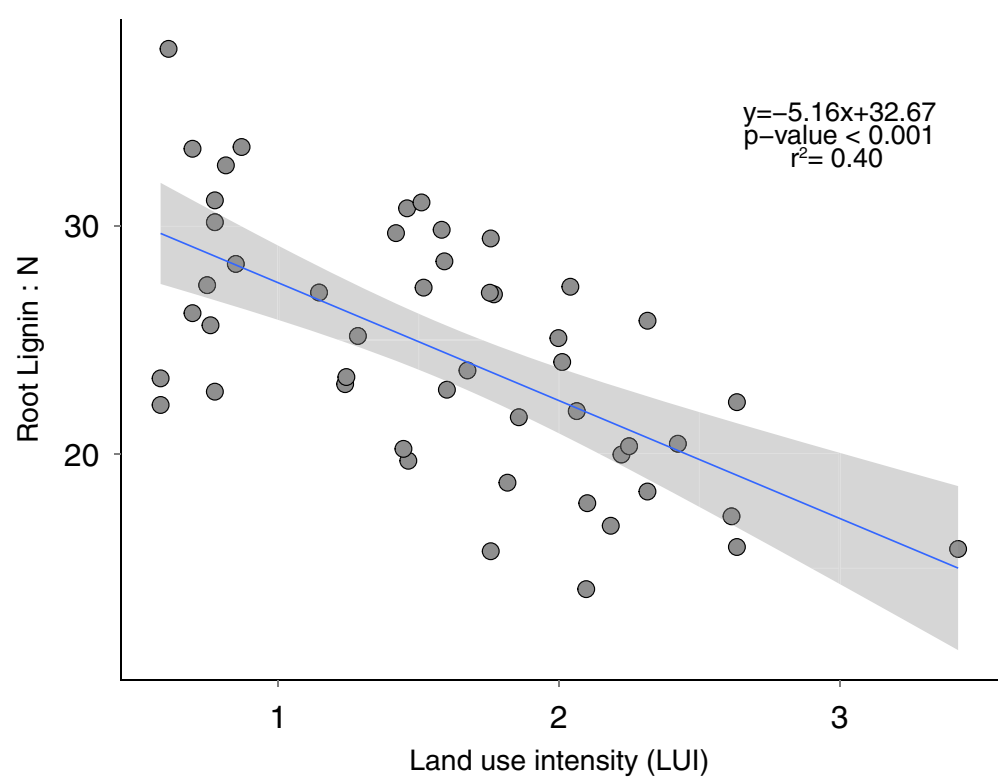

site $(r=-0.31, p<0.05)$. Root lignin: $\mathrm{N}$ ratios explained $11 \%$ of the decomposition of fine roots, while the sum of the environmental variables explained $24 \%$ of the variance (Fig. 4b).

\section{Discussion}

Our root decomposition study shows, in accordance with other experiments using the litterbag method, that
Fig. 4 Venn diagrams representing the partition of the variation of decomposition in response to environmental variables (continuous line) and litter chemistry (dashed line) for grassland (a) and forest ecosystems (b) in the HainichDün region. The total variation for each diagram is 100 . The intersection represents the amounts of variation explained by two different linear models we used for the analysis (the first model only including root litter quality and the second only including the environmental variables). The unexplained variation (residual variation) is represented by the number outside the circles. Partition of variation is expressed in $\%$. Adapted from Legendre (2008)

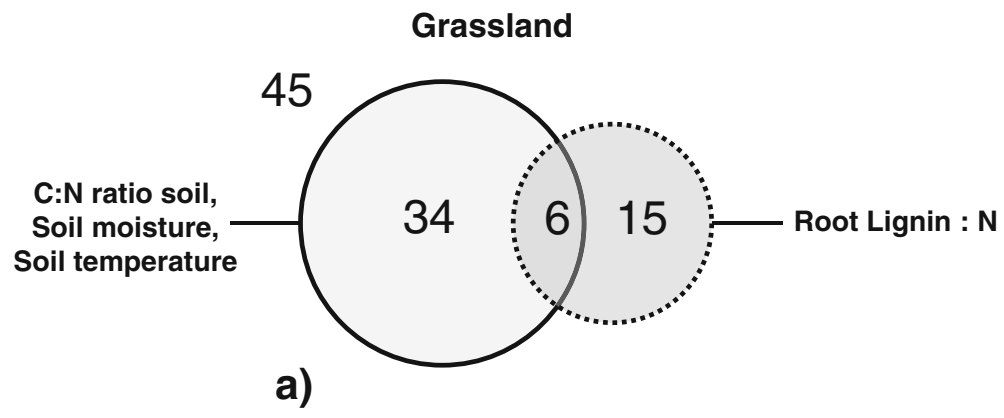

Forest

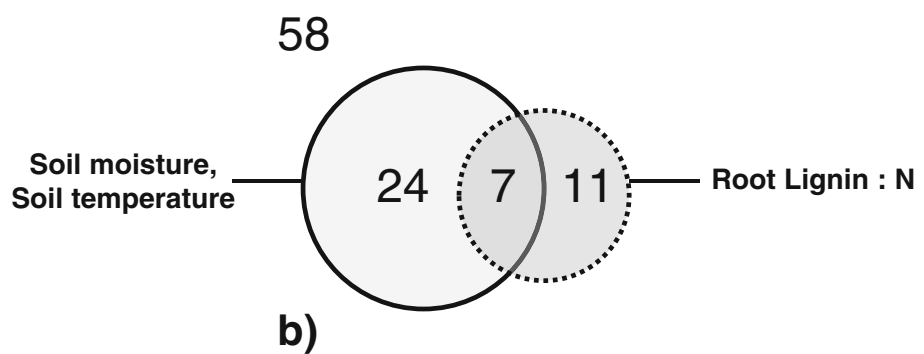


substantial decomposition can occur in litterbags in grasslands and forests, even in the absence of mechanical breakdown by macrofauna. Overall we observed relatively low rates of mass loss during the first year of decomposition. One factor to explain this is the relatively cold and dry conditions in temperate ecosystems. Parton et al. (2007) observed that leaf and root decomposition were slowest in cold dry regions such as tundra and boreal forests and fastest in tropical regions. We cannot exclude that absolute values might be affected by the experimental set-up (i.e. mesh size), but as all litterbags were the same, our discussion will focus on relative differences between study sites and root litter quality. In any case, with this work in three large regions in Germany we mostly provide an indication of the initial decomposition rates of fine roots and the factors which control this process in central European temperate grasslands and forests.

In comparison to previous studies on aboveground litter decomposition in temperate ecosystems (Butenschoen et al. 2011; Heim and Frey 2004), fine roots seem to lose mass at lower rates than leaves. Other studies also found that roots decompose more slowly than leaf litter of different species or ecosystem types (Vivanco and Austin 2006). Lower decomposition rates of root litter in comparison to aboveground litter may be a result of different nutritional requirements of decomposers above versus belowground. Environmental differences above and belowground could also overcome litter chemistry effects on decomposition (Hobbie et al. 2010).

Fine root decomposition rates in grasslands and forests

Overall, herbaceous roots (deployed in grasslands) decomposed twice as fast than roots from forests (deployed in forests) in all study regions (Table 5). This was true for both standardized and on-site collected litter. No common material was incubated in both grasslands and forests so this result can be related to differences in environmental conditions or in litter quality. We noted, for instance, higher soil moisture in grasslands than in forests (Table 3). Direct influences of moisture contents on fine root respiration, have been previously observed by Chen et al. (2000) for unsaturated soils. In grasslands, we further observed higher microbial biomass contents and higher $\mathrm{pH}$ values.

We also observed differences in fine root litter quality between herbaceous plants and trees (Table 4). For example greater lignin content in tree roots can control mass loss rates during the first stages of decomposition by its high resistance to enzymatic attack, as well as through physical interference with the decomposition of other cell wall fractions (Alexander 1977). Results of the global meta-analysis on fine root decomposition performed by Silver and Miya (2001) have also shown that decomposition rates of roots belonging to tree species were lower than those of graminoid roots due to lower $\mathrm{Ca}$ content and higher lignin: $\mathrm{N}$ ratios in tree roots.

Overall, we found up to 2 times higher stocks of fine roots and roughly 2 times faster decomposition rates in grasslands than in forests. These observations together with the results of recent studies in the same regions which have shown younger $\mathrm{C}$ in fine roots (Solly et al. 2013), and in the unprotected fraction of the soil organic matter (Herold et al. 2014) in grasslands, indicate faster fine root derived $\mathrm{C}$ cycling in grasslands than in forests. Interestingly these differences do not extent to the mineral associated fraction of the soil organic matter.

Site effects on fine root decomposition rates

As hypothesized, standardized root decomposition varied among the three study regions, with the highest rates (in grassland and forest) in the SCH study region, followed by ALB and HAI (Table 5). The decomposition patterns were the same for herbaceous and beech standardized root material deployments, indicating that the trends were not related to litter quality, but to differences in the soil decomposition environment between the study regions. HAI is intermediate in average climate and most soil properties (Table 2, Table 3), but has the lowest overall decomposition rates. The only factor we found that might explain this is that the soils in HAI were frozen for a longer number of days compared to ALB and $\mathrm{SCH}$. It has been shown that in soils with temperatures below $0{ }^{\circ} \mathrm{C}$ the microbial activity is slowed down. This is due to the rapid decline of unfrozen water content which can decrease the diffusion of substrates, nutrients, and waste products (Dioumaeva et al. 2002; Mikan et al. 2002; Ostroumov and Siegert 1996). Thus, also the degradation of fine roots may be slowed down, especially during the winter season in temperate ecosystems. In grasslands, we further observed considerably higher fine root decomposition in organic soils (Histosols and Gleysols present in the SCH study region) than in mineral soils in the $\mathrm{SCH}$ study region. This was probably related to the different soil properties, such 
as soil moisture and nutrient contents, which may in turn influence the soil biota which directly degrades the root litter.

After the removal of variance specific of the study regions and differences in organic and mineral soils, we observed that the decomposition of standardized fine root litter in grasslands decreased with increasing land use intensity. However, in comparison to other environmental properties which explained together $24 \%$ of fine root decomposition, land use intensity explained only a small proportion of variation (4\%). The negative relation observed between root decomposition and land use intensity is in our study mainly affected by the addition of $\mathrm{N}$ by fertilization. The lower need to mineralize organic $\mathrm{N}$ might slow down decomposition rates (Fog 1988). Knorr et al. (2005) reported that litter decomposition is inhibited by $\mathrm{N}$ additions when fertilization rates exceed by 2 to 20 times the atmospheric $\mathrm{N}$ deposition level. Since our fertilized plots received a maximum of $140 \mathrm{~kg} \mathrm{~N} \mathrm{ha}^{-1} \mathrm{yr}^{-1}$ and the average bulk $\mathrm{N}$ deposition levels for our study regions are on average $10 \mathrm{~kg} \mathrm{~N} \mathrm{ha}^{-1} \mathrm{yr}^{-1}$ (Schwarz et al. 2014), it is possible that the amount of added fertilizer inhibited the rates of root decomposition in fertilized ecosystems. In forests we did not observe land use effects on fine root decomposition.

Relevance of environmental site conditions and root litter chemistry on fine root decomposition

The lignin:N ratio explained the largest amount of variability ( $15 \%$ in grasslands and $11 \%$ in forests) of the mass loss of on-site collected fine root-litter in the grasslands and forests of the HAI region (Fig. 4). The remaining variability was explained by the sum of other environmental factors such as soil moisture and soil temperature, but also by the soil C:N ratios in grasslands (all environmental variables explained $34 \%$ of the variance in grasslands and $24 \%$ in forests) (Fig. 4). Although the lignin: $\mathrm{N}$ ratio itself merely describes the proportions of lignin to $\mathrm{N}$ without providing information about how lignin and $\mathrm{N}$ are distributed in plant organs, previous studies have shown that it is a valuable predictor for root decomposition (Bardgett et al. 1998; Hobbie 2005; Scheffer and Aerts 2000). Berg (1984) also concluded that the dominant factors for initial mass loss rates of root litter in a Scots pine forest are the relative amount of nutrients together with the initial lignin content. In particular, plant litter with higher $\mathrm{N}$ concentrations decomposes faster than its lower nitrogen counterpart, while plant litter with high levels of lignin decomposes slower (Berg 1984; Janssens et al. 2010). While in forest ecosystems we observed a decline of the decomposition rates for increasing lignin:N ratio of the litter, in grasslands we found the opposite relationship. The detected patterns may reflect the variation in the initial root chemistry among the fine roots collected on-site in grasslands and forests (Hobbie et al. 2010; Silver and Miya 2001). For instance we found high variability of $\mathrm{N}$ concentration in fine roots of grasslands (table 4). The lignin concentrations were instead relatively constant. On the other hand in forest sites the lignin concentrations in tree roots encompassed a relatively large variability.

In the grasslands of the HAI region we observed a negative relation between the LUI index and the lignin:N ratio of fine roots collected on-site (Fig. 3). This indicates that land use can affect fine root decomposition through its influence on litter quality. In forests, we observed a negative correlation between the lignin: $N$ ratio and the number of tree species per plot. However, this may be a function of our study design, as most of our plots are covered by pure European beech or mixed forests with more than one species and only a small number are pure Norway spruce (Picea abies (L.) H. Karst.) or Scots pine (Pinus sylvestris L.) forests. Therefore, higher lignin: $\mathrm{N}$ ratio in plots with a smaller number of tree species may be due to the higher amounts of lignin contained in European beech fine roots in comparison to, for example, coniferous tree species (Hobbie et al. 2010).

\section{Conclusions}

We observed that fine root decomposition in temperate grasslands is two times faster than in temperate forests within the range of measured values. This finding together with other observations of older $\mathrm{C}$ in fine roots and in the unprotected fractions of soil organic matter in forests overall indicate slower $\mathrm{C}$ turnover in forests compared to grasslands. In both grasslands and forests the decomposition patterns of standardized fine root litter were different for the three study regions, indicating that the trends are influenced by differences in environmental properties such as the soil biota and the soil microclimate. Land use intensity in grasslands, in particular $\mathrm{N}$ additions, also had an influence on fine root 
decomposition, though this amount of variation was small compared to the other abiotic factors. Within one study region, environmental variables explained the decomposition of both standardized and on-site collected litter. Additional variation for the on-site collected litter was explained by root lignin: $\mathrm{N}$ ratio, which in our study was influenced by land use; for example $\mathrm{N}$ addition in grasslands and tree species composition in forests.

Acknowledgments We thank Steffen Both, Jörg Hailer and Uta Schumacher for their help with the field work and technical organization. We thank Michael Bonkowski and Doreen Berner for their contribution to the microbial biomass analyses, Thomas Nauss for the climate data, Valentin Klaus and Stefanie Socher for their contribution to the vegetation survey. We thank Theresa Klötzing for technical support, and Ines Hilke and Birgit Fröhlich for the $\mathrm{CN}$ analysis. We thank the managers of the three exploratories, Swen Renner, Sonja Gockel, Kerstin Wiesner, and Martin Gorke for their work in maintaining the plot and project infrastructure; Simone Pfeiffer and Christiane Fischer for giving support through the central office, Michael Owonibi for managing the central data base, and Markus Fischer, Eduard Linsenmair, Dominik Hessenmöller, Jens Nieschulze, Daniel Prati, François Buscot, Ernst-Detlef Schulze, Wolfgang W. Weisser and the late Elisabeth Kalko for their role in setting up the Biodiversity Exploratories project. The work has been funded by the DFG Priority Program 1374 "Infrastructure-Biodiversity-Exploratories" (SCHR 1181/2-1) and the Max-Planck-Society. Field work permits were issued by the responsible state environmental offices of BadenWürttemberg, Thüringen, and Brandenburg (according to $\S 72$ BbgNatSchG). We thank the two anonymous referees for their helpful comments on the manuscript. Emily Solly and Jakob Zscheischler conducted this work as part of the International Max Planck Research School for Global Biogeochemical Cycles.

Open Access This article is distributed under the terms of the Creative Commons Attribution License which permits any use, distribution, and reproduction in any medium, provided the original author(s) and the source are credited.

\section{References}

Alexander M (1977) Introduction to soil microbiology. John Wiley $\&$ Sons.

Bardgett RD, Wardle DA, Yeates GW (1998) Linking aboveground and below-ground interactions: how plant responses to foliar herbivory influence soil organisms. Soil Biology and Biochemistry 30: 1867-1878. doi: http://dx.doi.org/10.1016/ S0038-0717(98)00069-8.

Berg B (1984) Decomposition of root litter and some factors regulating the process: Long-term root litter decomposition in a scots pine forest. Soil Biology and Biochemistry 16: 609-617. doi: http://dx.doi.org/10.1016/0038-0717(84)90081-6.

Berthrong ST, Jobbagy EG, Jackson RB (2009) A global metaanalysis of soil exchangeable cations, $\mathrm{pH}$, carbon, and nitrogen with afforestation. Ecol Appl 19:2228-2241. doi: 10.1890/08-1730.1

Bird JA, Torn MS (2006) Fine roots vs. Needles: a comparison of ${ }^{13} \mathrm{C}$ and ${ }^{15} \mathrm{~N}$ dynamics in a ponderosa pine forest soil. Biogeochemistry 79:361-382. doi:10.2307/20519837

Blüthgen N, Dormann CF, Prati D, Klaus VH, Kleinebecker T, Holzel N, Alt F, Boch S, Gockel S, Hemp A, Müller J, Nieschulze J, Renner SC, Schöning I, Schumacher U, Socher SA, Wells K, Birkhofer K, Buscot F, Oelmann Y, Rothenwöhrer C, Scherber C, Tscharntke T, Weiner CN, Fischer M, Kalko EKV, Linsenmair KE, Schulze ED, Weisser WW (2012) A quantitative index of land-use intensity in grasslands: integrating mowing, grazing and fertilization. Basic Appl Ecol 13:207-220. doi:10.1016/j.baae.2012.04.001

Boch S, Prati D, Mueller J, Socher S, Baumbach H, Buscot F, Gockel S, Hemp A, Hessenmoeller D, Kalko EKV, Linsenmair KE, Pfeiffer S, Pommer U, Schöning I, Schulze E-D, Seilwinder C, Weisser WW, Wells K, Fischer M (2013) High plant species richness indicates management-related disturbances rather than the conservation status of forests. Basic Appl Ecol 14:496-505. doi:10.1016/j.baae.2013.06.001

Bocock KL, Gilbert OJW (1957) The disappearance of leaf litter under different woodland conditions. Plant Soil 9:179-185. doi:10.1007/bf01398924

Bryant DM, Holland EA, Seastedt TR, Walker MD (1998) Analysis of litter decomposition in an alpine tundra. Can J Bot 76:1295-1304. doi:10.1139/b98-117

Butenschoen O, Scheu S, Eisenhauer N (2011) Interactive effects of warming, soil humidity and plant diversity on litter decomposition and microbial activity. Soil Biology and Biochemistry 43: 1902-1907. doi: http://dx.doi.org/10. 1016/j.soilbio.2011.05.011.

Carreiro MM, Sinsabaugh RL, Repert DA, Parkhurst DF (2000) Microbial enzyme shifts explain litter decay responses to simulated nitrogen deposition. Ecology 81:2359-2365. doi: $10.2307 / 177459$

Chen H, Harmon ME, Griffiths RP, Hicks W (2000) Effects of temperature and moisture on carbon respired from decomposing woody roots. Forest Ecology and Management 138: 51-64. doi: http://dx.doi.org/10.1016/S0378-1127(00)00411-4.

Chen H, Harmon ME, Sexton J, Fasth B (2002) Fine-root decomposition and $\mathrm{N}$ dynamics in coniferous forests of the pacific northwest, USA. Can J For Res 32:320-331. doi:10.1139/ $\mathrm{x} 01-202$

Cortina J, Vallejo V (1994) Effects of clearfelling on forest floor accumulation and litter decomposition in a radiata pine plantation. For Ecol Manag 70:299-310

Crawley MJ (2007) Regression. The R Book. John Wiley \& Sons, Ltd.

Cusack DF, Chou WW, Yang WH, Harmon ME, Silver WL, Lidet (2009) Controls on long-term root and leaf litter decomposition in Neotropical forests. Global Change Biology.

R Development Core Team (2013) A language and environment for statistical computing. R Foundation for Statistical Computing, Vienna, Austria, http://www.R-project.org/, (last access: 24 April 2014).

Dickinson NM, Polwart A (1982) The effect of mowing regime on an amenity grassland ecosystem: above-and below-ground components. J Appl Ecol 19:569-577. doi:10.2307/2403489

Dioumaeva I, Trumbore S, Schuur EAG, Goulden ML, Litvak M, Hirsch AI (2002) Decomposition of peat from upland boreal 
forest: temperature dependence and sources of respired carbon. J Geophys Res Atmos 107:8222. doi:10.1029/2001jd000848

Fahey TJ, Hughes JW, Pu M, Arthur MA (1988) Root decomposition and nutrient flux following whole-tree harvest of northern hardwood forest. For Sci 34:744-768

Fischer M, Bossdorf O, Gockel S, Hänsel F, Hemp A, Hessenmöller D, Korte G, Nieschulze J, Pfeiffer S, Prati D, Renner S, Schöning I, Schumacher U, Wells K, Buscot F, Kalko EKV, Linsenmair KE, Schulze ED, Weisser WW (2010) Implementing large-scale and long-term functional biodiversity research: the biodiversity exploratories. Basic Appl Ecol 11:473-485. doi:10.1016/j.baae.2010.07.009

Fog K (1988) The effect of added nitrogen on the rate of decomposition of organic matter. Biol Rev 63:433-462. doi:10. 1111/j.1469-185X.1988.tb00725.x

Harmon ME, Silver WL, Fasth B, Chen HUA, Burke IC, Parton WJ, Hart SC, Currie WS, Lidet (2009) Long-term patterns of mass loss during the decomposition of leaf and fine root litter: an intersite comparison. Glob Chang Biol 15:1320-1338. doi:10.1111/j.1365-2486.2008.01837.x

Heim A, Frey B (2004) Early stage litter decomposition rates for Swiss forests. Biogeochemistry 70:299-313. doi:10.1007/ s10533-003-0844-5

Herold N, Schöning I, Michalzik B, Trumbore SE, Schrumpf M. (2014) Controls on soil carbon storage and turnover in German landscapes. Biogeochemistry 119:435-451. doi:10. 1007/s10533-014-9978-x

Hobbie SE (1992) Effects of plant species on nutrient cycling. Trends in Ecology \& Evolution 7: 336-339. doi: http:// dx.doi.org/10.1016/0169-5347(92)90126-V.

Hobbie S (2005) Contrasting effects of substrate and fertilizer nitrogen on the early stages of litter decomposition. Ecosystems 8:644-656. doi:10.1007/s10021-003-0110-7

Hobbie SE, Vitousek PM (2000) Nutrient limitation of decomposition in Hawaiian forests. Ecology 81:1867-1877. doi:10. 1890/0012-9658(2000)081[1867:nlodih]2.0.co;2

Hobbie S, Oleksyn J, Eissenstat D, Reich P (2010) Fine root decomposition rates do not mirror those of leaf litter among temperate tree species. Oecologia 162:505-513. doi:10. 1007/s00442-009-1479-6

Janssens IA, Dieleman W, Luyssaert S, Subke JA, Reichstein M, Ceulemans R, Ciais P, Dolman AJ, Grace J, Matteucci G, Papale D, Piao SL, Schulze ED, Tang J, Law BE (2010) Reduction of forest soil respiration in response to nitrogen deposition. Nature Geosciences 3: 315-322. doi: http://www. nature.com/ngeo/journal/v3/n5/suppinfo/ngeo844_S1.html.

Joergensen RG (1996) The fumigation-extraction method to estimate soil microbial biomass: Calibration of the $\mathrm{k}_{\mathrm{EC}}$ value. Soil Biology and Biochemistry 28: 25-31. doi: http:// dx.doi.org/10.1016/0038-0717(95)00102-6.

Knorr M, Frey SD, Curtis PS (2005) Nitrogen additions and litter decomposition: a meta analysis. Ecology 86:3252-3257. doi: $10.1890 / 05-0150$

Kögel-Knabner I (2002) The macromolecular organic composition of plant and microbial residues as inputs to soil organic matter. Soil Biology and Biochemistry 34: 139-162. doi: http://dx.doi.org/10.1016/S0038-0717(01)00158-4.

Kramer C, Trumbore S, Fröberg M, Cisneros Dozal LM, Zhang D, Xu X, Santos GM, Hanson PJ (2010) Recent ( $<4$ year old) leaf litter is not a major source of microbial carbon in a temperate forest mineral soil. Soil Biology and Biochemistry 42: 10281037. doi: http://dx.doi.org/10.1016/j.soilbio.2010.02.021.

Kurz-Besson C, Coûteaux M-M, Thiéry JM, Berg B, Remacle J (2005) A comparison of litterbag and direct observation methods of Scots pine needle decomposition measurement. Soil Biology and Biochemistry 37: 2315-2318. doi: http:// dx.doi.org/10.1016/j.soilbio.2005.03.022.

Legendre P (2008) Studying beta diversity: ecological variation partitioning by multiple regression and canonical analysis. $\mathrm{J}$ Plant Ecol 1:3-8. doi:10.1093/jpe/rtm001

Liao C, Luo Y, Fang C, Li B (2010) Ecosystem Carbon Stock Influenced by Plantation Practice: Implications for Planting Forests as a Measure of Climate Change Mitigation. PLoS One 5. doi: e1086710.1371/journal.pone.0010867.

Luyssaert S, Hessenmöller D, von Lüpke N, Kaiser S, Schulze ED (2011) Quantifying land use and disturbance intensity in forestry, based on the self-thinning relationship. Ecol Appl 21:3272-3284

Mendez-Millan M, Dignac MF, Rumpel C, Rasse DP, Derenne S (2010) Molecular dynamics of shoot vs. root biomarkers in an agricultural soil estimated by natural abundance $13 \mathrm{C}$ labelling. Soil Biology and Biochemistry 42: 169-177. doi: http://dx.doi.org/10.1016/j.soilbio.2009.10.010.

Mikan CJ, Schimel JP, Doyle AP (2002) Temperature controls of microbial respiration in arctic tundra soils above and below freezing. Soil Biology and Biochemistry 34: 1785-1795. doi: http://dx.doi.org/10.1016/S0038-0717(02)00168-2.

Olson JS (1963) Energy storage and the balance of producers and decomposers in ecological systems. Ecology 44:322-331

Ostertag R, Hobbie SE (1999) Early stages of root and leaf decomposition in Hawaiian forests: effects of nutrient availability. Oecologia 121:564-573. doi:10.1007/ s004420050963

Ostroumov VE, Siegert C (1996) Exobiological aspects of mass transfer in microzones of permafrost deposits. Advances in Space Research 18: 79-86. doi: http://dx.doi.org/10.1016/ 0273-1177(96)00002-6.

Parton W, Silver WL, Burke IC, Grassens L, Harmon ME, Currie WS, King JY, Adair EC, Brandt LA, Hart SC, Fasth B (2007) Global-scale similarities in nitrogen release patterns during long-term decomposition. Science 315:361-364. doi:10. 1126/science. 1134853

Prescott C, Blevins L, Staley C (2000) Effects of clear-cutting on decomposition rates of litter and forest floor in forests of British Columbia. Can J For Res 30:1751-1757

Raessler M, Rothe J, Hilke I (2005) Accurate determination of Cd, $\mathrm{Cr}, \mathrm{Cu}$ and $\mathrm{Ni}$ in woodlice and their skins - is moulting a means of detoxification? Science of The Total Environment 337: 83-90. doi: http://dx.doi.org/10.1016/j.scitotenv.2004. 07.008 .

Rasse DP, Rumpel C, Dignac MF (2005) Is soil carbon mostly root carbon? mechanisms for a specific stabilisation. Plant Soil 269:341-356. doi:10.1007/s11104-004-0907-y

Sanaullah M, Chabbi A, Leifeld J, Bardoux G, Billou D, Rumpel C (2011) Decomposition and stabilization of root litter in topand subsoil horizons: what is the difference? Plant Soil 338: 127-141. doi:10.1007/s11104-010-0554-4

Sankaran M, Augustine DJ (2004) Large herbivores suppress decomposer abundance in a semiarid grazing ecosystem. Ecology 85:1052-1061. doi:10.2307/3450320 
Scheffer RA, Aerts R (2000) Root decomposition and soil nutrient and carbon cycling in two temperate fen ecosystems. Oikos 91:541-549. doi:10.1034/j.1600-0706.2000.910316.x

Schmidt MWI, Torn MS, Abiven S, Dittmar T, Guggenberger G, Janssens IA, Kleber M, Kögel-Knabner I, Lehmann J, Manning DAC, Nannipieri P, Rasse DP, Weiner S, Trumbore SE (2011) Persistence of soil organic matter as an ecosystem property. Nature 478:49-56. doi:10.1038/nature10386

Schwarz MT, Bischoff S, Blaser S, Boch S, Schmitt B, Thieme L, Fischer M, Michalzik B, Schulze E-D, Siemens J, Wilcke W (2014) More efficient aboveground nitrogen use in more diverse Central European forest canopies. Forest Ecology and Management 313: 274-282. doi: http://dx.doi.org/10. 1016/j.foreco.2013.11.021.

Semmartin M, Garibaldi L, Chaneton E (2008) Grazing history effects on above- and below-ground litter decomposition and nutrient cycling in two co-occurring grasses. Plant Soil 303: 177-189. doi:10.1007/s11104-007-9497-9

Shannon CE (1948) A mathematical theory of communication. Bell Syst Tech J 27:379-423

Silver WL, Miya RK (2001) Global patterns in root decomposition: comparisons of climate and litter quality effects. Oecologia 129:407-419

Socher SA, Prati D, Boch S, Mueller J, Baumbach H, Gockel S, Hemp A, Schöning I, Wells K, Buscot F, Kalko EKV, Linsenmair KE, Schulze E-D, Weisser WW, Fischer M (2013) Interacting effects of fertilization, mowing and grazing on plant species diversity of 1500 grasslands in Germany differ between regions. Basic Appl Ecol 14:126136. doi:10.1016/j.baae.2012.12.003

Solly E, Schöning I, Boch S, Müller J, Socher SA, Trumbore SE, Schrumpf M (2013) Mean age of carbon in fine roots from temperate forests and grasslands with different management. Biogeosciences 10:4833-4843. doi:10.5194/bg-10-48332013

Sun T, Mao Z, Dong L, Hou L, Song Y, Wang X (2012) Further evidence for slow decomposition of very fine roots using two methods: litterbags and intact cores. Plant Soil. doi:10.1007/ s11104-012-1457-3

Taboada MA, Lavado RS (1988) Grazing effects of the bulk density in a natraquoll of the flooding pampa of Argentina. J Range Manag 41:500-503. doi:10.2307/3899526

Vance ED, Brookes PC, Jenkinson DS (1987) An extraction method for measuring soil microbial biomass C. Soil Biology and Biochemistry 19: 703-707. doi: http:// dx.doi.org/10.1016/0038-0717(87)90052-6.

Vivanco L, Austin A (2006) Intrinsic effects of species on leaf litter and root decomposition: a comparison of temperate grasses from North and South America. Oecologia 150:97107. doi:10.1007/s00442-006-0495-Z

Yang H, Yan R, Chen H, Zheng C, Lee DH, Liang DT (2005) Indepth investigation of biomass pyrolysis based on three major components: hemicellulose, cellulose and lignin. Energy Fuel 20:388-393. doi:10.1021/ef0580117 